\section{Determination of the Physical, Chemical, and Hydraulic Characteristics of Locally Available Materials for Formulating Extensive Green Roof Substrates}

\author{
Nikolaos Ntoulas ${ }^{1,3}$, Panayiotis A. Nektarios ${ }^{1}$, Thomais-Evelina \\ Kapsali $^{1}$, Maria-Pinelopi Kaltsidi ${ }^{1}$, Liebao Han², and Shuxia Yin ${ }^{2}$
}

AdDITIONAL INDEX wORDs. pumice, crushed tiles and bricks, zeolite, thermally treated clay, compost, peat

\begin{abstract}
Summary. Several locally available materials were tested to create an optimized growth substrate for arid and semiarid Mediterranean extensive green roofs. The study involved a four-step screening procedure. At the first step, 10 different materials were tested including pumice (Pum), crushed tiles grade $1-2 \mathrm{~mm}\left(\mathrm{~T}_{1-2}\right)$, 2-4 mm ( $\left.\mathrm{T}_{2-4}\right), 5-8 \mathrm{~mm}\left(\mathrm{~T}_{5-8}\right), 5-16 \mathrm{~mm}\left(\mathrm{~T}_{5-16}\right)$, and 4-22 $\mathrm{mm}\left(\mathrm{T}_{4-22}\right)$; crushed bricks of either $2-4 \mathrm{~mm}\left(\mathrm{~B}_{2-4}\right)$ or $2-8 \mathrm{~mm}\left(\mathrm{~B}_{2-8}\right)$; a thermally treated clay (TC); and zeolite (Zeo). All materials were tested for their particle size distribution, $\mathrm{pH}$, and electrical conductivity (EC). The results were compared for compliance with existing guidelines for extensive green roof construction. From the first step, the most promising materials were shown to include Pum, Zeo, $T_{5-8}, T_{5-16}$, and TC, which were then used at the second stage to develop mixtures between them. Tests at the second stage included particle size distribution and moisture potential curves. Pumice mixed with TC provided the best compliance with existing guidelines in relation to particle size distribution, and it significantly increased moisture content compared with the mixes of Pum with $T_{5-8}$ and $T_{5-16}$. As a result, from the second screening step, the best performing substrate was Pum mixed with TC and Zeo. The third stage involved the selection of the most appropriate organic amendment of the growing substrate. Three composts having different composition and sphagnum peat were analyzed for their chemical and physical characteristics. The composts were a) garden waste compost (GWC), b) olive (Olea europaea L.) mill waste compost (OMWC), and c) grape (Vitis vinifera L.) marc compost (GMC). It was found that the peatamended substrate retained increased moisture content compared with the compostamended substrates. The fourth and final stage involved the evaluation of the environmental impact of the final mix with the four different organic amendments based on their first flush nitrate nitrogen $\left(\mathrm{NO}_{3}{ }^{-}-\mathrm{N}\right)$ leaching potential. It was found that GWC and OMWC exhibited increased $\mathrm{NO}_{3}{ }^{-}-\mathrm{N}$ leaching that initially reached 160 and $92 \mathrm{mg} \cdot \mathrm{L}^{-1}$ of $\mathrm{NO}_{3}{ }^{-}-\mathrm{N}$ for OMWC and GWC, respectively. By contrast, peat and GMC exhibited minimal $\mathrm{NO}_{3}{ }^{-}-\mathrm{N}$ leaching that was slightly above the maximum contaminant level of $10 \mathrm{mg} \cdot \mathrm{L}^{-1}$ of $\mathrm{NO}_{3}{ }^{-} \mathrm{N}\left(17.3\right.$ and $14.6 \mathrm{mg} \cdot \mathrm{L}^{-1}$ of $\mathrm{NO}_{3}{ }^{-} \mathrm{N}$ for peat and GMC, respectively). The latter was very brief and lasted only for the first 100 and $50 \mathrm{~mL}$ of effluent volume for peat and GMC, respectively.
\end{abstract}

$\mathrm{G}$ reen roofs are technological solutions for increasing greening within the built urban environment while offering numerous environmental and aesthetic advantages (Dunnett and Kingsbury, 2010; Getter and Rowe, 2006; Spronken-Smith and Oke, 1998; Takebayashi and Moriyama, 2009). However, several of these advantages, such as storm water management and amelioration of the urban heat island effect, are expected to occur only if green roofs are implemented in adequately large urban scales (Akbari et al., 2001; Getter and Rowe, 2006). In addition, the positive impact of urban greening is expected to have significant ramifications when it participates in a green network, especially when it is interconnected with neighboring suburban green bodies such as forests, mountains, and hillslopes. The creation of an elevated urban greenway system through green roof construction and networking demands broad applications over extended surfaces of existing city buildings.

Thus, in an effort to improve the environment of contemporary cities, it is mandatory to construct green roof systems on existing building rooftops. Unfortunately, in most cases existing buildings are aged with minimal load-bearing capacity. In such cases, extensive green roof systems are the only option since their weight $\left(90-150 \mathrm{~kg} \cdot \mathrm{m}^{-2}\right)$ is tolerated by most existing building frameworks. Extensive green roofs are characterized by minimal substrate depth $(25-150 \mathrm{~mm})$ and are planted either with succulent or herbaceous plants that demand minimal maintenance. An alternative solution, especially for semiarid and arid climates, is the use of adaptive green roofs (Kotsiris et al., 2013; Ntoulas et al., 2013a) that use a minimal substrate depth in conjunction with droughttolerant plants and prudent irrigation applications.

Since, it is acknowledged that the heaviest part of an extensive green roof system is the growing substrate (Scrivens, 1990), selection of appropriate lightweight materials is of utmost interest. However, apart from the weight factor, substrates must provide sustainable plant growth under the harsh and extreme conditions of a green roof that involve increased solar radiation, wind drifts, and occasionally significant shading from adjacent buildings. Thus, green roof substrates must fulfill several criteria, such as maintaining adequate moisture for plant growth, facilitating the quick removal of

\begin{tabular}{llll}
\hline $\begin{array}{l}\text { Units } \\
\begin{array}{l}\text { To convert U.S. to SI, } \\
\text { multiply by }\end{array}\end{array}$ & U.S. unit & SI unit & $\begin{array}{l}\text { To convert SI to U.S., } \\
\text { multiply by }\end{array}$ \\
\hline 0.1 & bar & $\mathrm{MPa}$ & 10 \\
29.5735 & $\mathrm{fl} \mathrm{oz}$ & $\mathrm{mL}$ & 0.0338 \\
2.54 & inch $(\mathrm{es})$ & $\mathrm{cm}$ & 0.3937 \\
25.4 & inch $(\mathrm{es})$ & $\mathrm{mm}$ & 0.0394 \\
0.4536 & $\mathrm{lb}$ & $\mathrm{kg}$ & 2.2046 \\
4.8824 & $\mathrm{lb} / \mathrm{ft}^{2}$ & $\mathrm{~kg} \cdot \mathrm{m}^{-2}$ & 0.2048 \\
16.0185 & $\mathrm{lb} / \mathrm{ft}^{3}$ & $\mathrm{~kg} \cdot \mathrm{m}^{-3}$ & 0.0624 \\
1000 & $\mathrm{mmh} / \mathrm{cm}$ & $\mu \mathrm{SS} \cdot \mathrm{cm}^{-1}$ & 0.0010 \\
1.7300 & $\mathrm{Oz} / \mathrm{inch}^{3}$ & $\mathrm{~g} \cdot \mathrm{cm}^{-3}$ & 0.5780 \\
1 & $\mathrm{ppm}$ & $\mathrm{mg} \cdot \mathrm{kg}^{-1}$ & 1 \\
1 & $\mathrm{ppm}$ & $\mathrm{mg} \cdot \mathrm{L}^{-1}$ & 1 \\
$\left({ }^{\circ} \mathrm{F}-32\right) \div 1.8$ & ${ }^{\circ} \mathrm{F}$ & ${ }^{\circ} \mathrm{C}$ & $\left({ }^{\circ} \mathrm{C} \times 1.8\right)+32$ \\
& & &
\end{tabular}


excess water, providing support and anchoring for the plants, providing nutrients, and possessing a $\mathrm{pH}$ and an EC appropriate for plant growth. In addition, green roof substrates must be able to withstand wind erosion, as wind drifts are a significant factor on building roofs (Beattie and Berghage, 2004). The materials that have customarily constituted green roof substrate mixtures are mainly of inorganic nature (Beattie and Berghage, 2004; Thuring et al., 2010) such as calcined clay, Zeo (Nektarios et al., 2011a, 2015), perlite (Kotsiris et al., 2012, 2013), sand, heat-expanded shale (Rowe et al., 2006), heat-expanded slate (Olszewski et al., 2010), Pum (Ntoulas et al., 2012, 2013b), and lava (Nektarios et al., 2003; Tsiotsiopoulou et al., 2003).

Organic substances, such as peat and composts, have also been used, but at a smaller percentage to prevent substrate subsidence due to decomposition (Williams et al., 2010). Given the effort to minimize the negative environmental impact of the horticultural use of peat (Kotsiris et al., 2012) regarding both peatland degradation and total carbon dioxide $\left(\mathrm{CO}_{2}\right)$ emissions, composts can offer an alternative choice as green roof organic constituents (Nektarios et al., 201la; Ntoulas et al., 2012, 2013a, 2013b).

Beattie and Berghage (2004) indicated that an extensive green roof growth substrate must consist primarily of inorganic materials, while large quantities of composted or other organic substances should be

This article is part of an MSc thesis submitted to the Department of Crop Science, Agricultural University of Athens by Thomais-Evelina Kapsali.

The project (Urban BioRoof) with the code number $12 \mathrm{CHN} 136$ was funded by the General Secretariat of Research and Technology under the Operational Programme "Competitiveness and Entrepreneurship" (EPAN II) and by the Regional Operational Programmes of the five Regions of transitional support, under the Action "Bilateral Research and Technological Cooperation between Greece and China 2012-2014".

The mention of a trademark, proprietary product, or vendor does not imply endorsement by the authors nor does it imply approval to the exclusion of other products that may also be suitable.

${ }^{1}$ Laboratory of Floriculture and Landscape Architecture, Department of Crop Science, Agricultural University of Athens, Iera Odos 75, Athens 118 55, Greece

${ }^{2}$ Institute of Turfgrass Science, Beijing Forestry University, No. 35 Qinghua East Road, Beijing 100083 , China

${ }^{3}$ Corresponding author. E-mail: ntoulas@aua.gr. avoided. Rowe et al. (2006) evaluated the use of heat-expanded shale in the establishment, growth, and survival of several stonecrops (Sedum sp.) and native wild plants. The researchers evaluated $60 \%, 70 \%, 80 \%$, $90 \%$, and $100 \%$ of heat-expanded shale participation in the substrate mix in conjunction with varying proportions of sand, peat, and compost. They concluded that the substrates with higher shale contents resulted in slightly reduced plant growth and lower visual quality characteristics, irrespective of the plant species studied, whereas moderately high quantities of heat-expanded shale $(80 \%)$ did not have any negative effects on plant growth and reduced the load weight of the structure. Thuring et al. (2010) evaluated the effects of expanded clay and shale amended with spent mushroom compost on the growth and dry weight of five succulent and herbaceous plants. Despite some individual plant responses, they found that plants grew better in expanded clay compared with expanded shale because of its enhanced moisture- and nutrientholding capacity. This was especially profound during the drought-stress periods.

In addition to the physical and chemical characteristics of a green roof substrate, an environmental parameter needs to be taken into consideration. More specifically, an issue that has only superficially been investigated concerns the fact that green roof substrates must be environmentally friendly either by absorbing potential pollutants or by having minimal pollutant leaching capacity themselves. To date, only sparse leaching studies have investigated the leaching potential of green roof systems mainly after the application of fertilizers and pesticides. Nikologianni et al. (2009) reported that metalaxyl-m leaching was enhanced in intensive type substrates without organic fraction or amended with reduced organic portion. Vijayaraghavan et al. (2012) reported that green roof systems were prone to $\mathrm{NO}_{3}{ }^{-} \mathrm{N}$ and phosphate leaching. Czemiel Berndtsson et al. (2008) reported that ammonium $\left(\mathrm{NH}_{4}{ }^{-} \mathrm{N}\right)$ and $\mathrm{NO}_{3}{ }^{-}-\mathrm{N}$, phosphorus $(\mathrm{P})$, zinc $(\mathrm{Zn})$, and copper $(\mathrm{Cu})$ exhibited increased concentrations in the leachate of the first runoff (first flush effect) compared with latter runoff events.
Apart from the technical aspects of green roof substrate formulation, financial issues are also of major importance. Under the current economic restraints, it is obligatory to reduce construction costs if green roofs are to be widely applied. Substrates are considered as one of the most expensive parts of a green roof system reaching a proportion of $40 \%$ to $50 \%$ of the total construction cost depending on the applied depth in each case. Thus, it is necessary to investigate the potential of using locally available materials that will be suitable as green roof substrate constituents. The materials should be inexpensive, should have the capacity to conform to existing guidelines, and should possess characteristics that will improve the capacities of substrates currently available in the market.

Locally available inorganic materials include Pum, crushed bricks and tiles, TC, and Zeos. Pumice is a porous volcanic rock, which is chemically inert. It is created by volcanic action, and the porosity of the material results from the voids created by the entrapped vapors during the cooling process of lava. Because of its light weight, absorbency, and structural resistance, Pum has been used in numerous agricultural applications including green roof systems (Kotsiris et al., 2012, 2013; Nektarios et al., 201la, 2015; Ntoulas et al., 2012, 2013a, 2013b).

Crushed tiles and bricks are deformed or defective residues from the masonry industry that have been crushed and sieved. Their basic constituent is kneaded clay soil that has been fire hardened or air-dried. They have been promoted in the green roof industry as recyclable materials that are eco-friendly, having the advantage of adding a terra-cotta color to the green roofs.

Clinoptilolite Zeos are hydrated aluminosilicates and characterized by high surface areas and high cation exchange capacities with a $5: 1$ silica to alumina ratio. Clinoptilolite Zeo has the capacity to absorb and retain $\mathrm{NH}_{4}{ }^{+} \mathrm{N}$ and potassium $(\mathrm{K})$ cations in its microtunneling structure, which are then provided to the plants in a slow-release mode of action (Huang and Petrovic, 1994).

Thermally treated clay is marketed as providing increased waterholding and cation exchange capacity. The exact nature of the clay as well as 
the treatment procedure fall under proprietary restrictions.

The aim of the present study was to evaluate different locally available materials that are capable of participating in an extensive green roof growth substrate according to existing guidelines either as stand-alone products or in various mixes. In addition, it was of major interest to evaluate the environmental behavior of the final mixes, such as their nitrate leaching potential at first flush.

\section{Materials and methods}

Based on the existing literature (Beattie and Berghage, 2004), the inorganic portion of a substrate should be $\approx 80 \%$ to $85 \%$ while the remaining $15 \%$ to $20 \%$ should be of organic nature. Because of the increased participation of the inorganic portion, a four-step conceptual model was employed in the current study. More specifically, 10 inorganic materials were identified and tested independently as potential constituents of an extensive green roof substrate.

At the second level, different inorganic materials from those selected at the first level were mixed together in various proportions and their physical and chemical characteristics were determined. From this procedure, a final mixture of inorganic constituents was expected to be identified based on several criteria, including existing Forschungsgesellschaft Landschaftsentwicklung Landschaftsbau (FLL, 2008) guidelines for extensive green roof types. After establishing the inorganic portion of the mixture, which constitutes the backbone of the substrate, different organic sources needed to be identified to determine the remaining $15 \%$ to $20 \%$ of the final substrate. Thus, at the third level, the final inorganic mixture selected at the previous level was mixed with four different organic sources that included three composts and a sphagnum peat serving as a control. The new mixes were again analyzed for their physical and chemical characteristics. At the fourth and final level, each of the four mixtures composed of different organic sources was investigated for its first flush $\mathrm{NO}_{3}{ }^{-}-\mathrm{N}$ leaching capacity in laboratory microlysimeters to determine their environmental impact.

\section{Selected materials}

The selected materials were divided based on their nature into inorganic and organic ones. The inorganic materials included Pum; crushed tiles grade $\mathrm{T}_{1-2}, \mathrm{~T}_{2-4}, \mathrm{~T}_{5-8}, \mathrm{~T}_{5-16}$, and $\mathrm{T}_{4-22}$; crushed bricks of either $\mathrm{B}_{2-4}$ or $\mathrm{B}_{2-8} ; \mathrm{Zeo}$; and TC (Table $\mathrm{l}$ ).

The selected organic constituents were three different composts produced in Greece. The first was a GWC and was composed of straw, sawdust, yard waste (clippings and wood chips), and dairy cow, horse, and chicken manure (Lambda Cambanis, Pikermi, Greece). The second was a GMC and was composed of grape fruit and pits from winery production (Labrou Brothers, Koropi, Greece) whereas the third was an OMWC and was produced from co-composting olive stones, olive leaves, and olive mill wastewater (Biocyclic Compost; Samira Eisenbach, Kalamata, Greece). Peat was a Lithuanian sphagnum peat with a corrected $\mathrm{pH}$ of 5.5 and served as a control.

\section{Physical and chemical characteristics determination}

Measurements included particle size distribution, $\mathrm{pH}, \mathrm{EC}$, moisture potential curves from 0 to 1000 $\mathrm{mm}$ suction of substrate mixtures, determination of the hydraulic conductivity of the final substrate mixes, and substrate dry weight and weight at saturation. For the organic constituents, the organic content was also determined along with the carbon to nitrogen ratio $(\mathrm{C}: \mathrm{N})$ and their content in $\mathrm{N}, \mathrm{P}, \mathrm{K}$, calcium (Ca), magnesium $(\mathrm{Mg})$, sodium $(\mathrm{Na})$, iron $(\mathrm{Fe})$, manganese, $\mathrm{Zn}, \mathrm{Cu}$, and boron.

Table 1. Physical and chemical characteristics of selected inorganic green roof substrate constituents. Values are the mean of three replications.

\begin{tabular}{|c|c|c|c|c|c|c|}
\hline \multirow[b]{2}{*}{ Material } & \multirow{2}{*}{$\begin{array}{l}\text { Code } \\
\text { name }^{z}\end{array}$} & \multirow{2}{*}{$\begin{array}{c}\text { Particle size } \\
\text { distribution } \\
(\mathrm{mm})^{\mathrm{y}}\end{array}$} & \multirow{2}{*}{$\begin{array}{l}\text { Particle size } \\
\text { distribution } \\
\text { compliance }^{\mathrm{x}}\end{array}$} & $\mathrm{pH}$ & $\underset{\left(\mu S \cdot \mathrm{cm}^{-1}\right)^{\mathrm{w}}}{\mathrm{EC}}$ & \multirow[b]{2}{*}{ Manufacturer } \\
\hline & & & & \multicolumn{2}{|c|}{ mean $\pm S E$} & \\
\hline Tile $2-4$ & $\mathrm{~T}_{2-4}$ & $2-4$ & No & $8.22 \pm 0.02$ & $894.0 \pm 4.93$ & Kontogiannis \\
\hline Tile $5-8$ & $\mathrm{~T}_{5-8}$ & $5-8$ & No & $8.18 \pm 0.02$ & $813.0 \pm 2.89$ & Kontogiannis \\
\hline Brick 2-4 & $\mathrm{B}_{2-4}$ & $2-4$ & No & $10.20 \pm 0.03$ & $1,618.0 \pm 7.21$ & Kontogiannis \\
\hline Brick 2-8 & $\mathrm{B}_{2-8}$ & $2-8$ & No & $10.42 \pm 0.02$ & $1,071.0 \pm 9.07$ & Kontogiannis \\
\hline $\begin{array}{l}\text { Thermally } \\
\text { treated clay }\end{array}$ & $\mathrm{TC}$ & $0.5-8$ & No & $7.75 \pm 0.01$ & $435.0 \pm 4.16$ & Geohellas, Athens, Greece \\
\hline
\end{tabular}

$\mathrm{EC}=$ electrical conductivity.

${ }^{2} \mathrm{~T}=$ crushed tiles of various grades indicated by their subscripts, $\mathrm{B}=$ crushed bricks of various grades indicated by their subscripts

${ }^{\mathrm{y}} \mathrm{l} \mathrm{mm}=0.0394$ inch

${ }^{x}$ According to Forschungsgesellschaft Landschaftsentwicklung Landschaftsbau (2008).

${ }^{\mathrm{w}} 1 \mu \mathrm{S} \cdot \mathrm{cm}^{-1}=0.0010 \mathrm{mmho} / \mathrm{cm}$. 


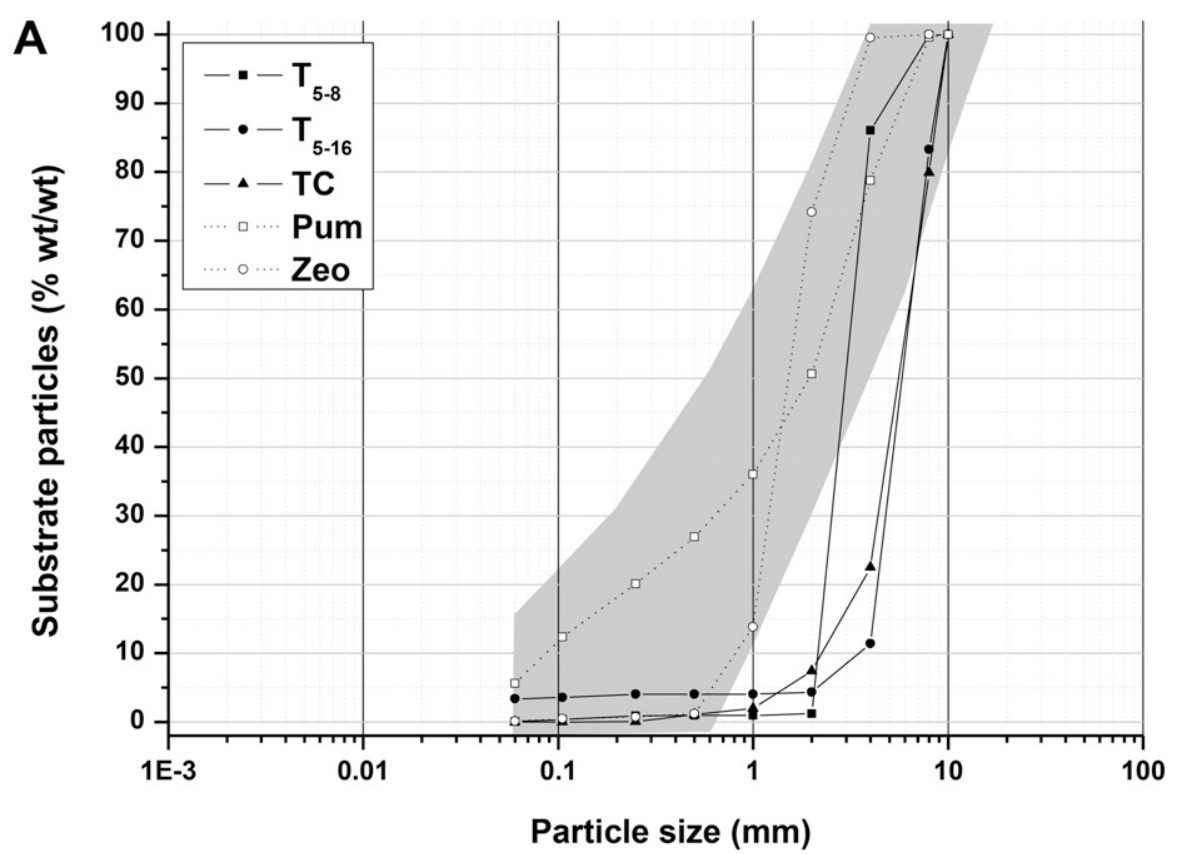

B

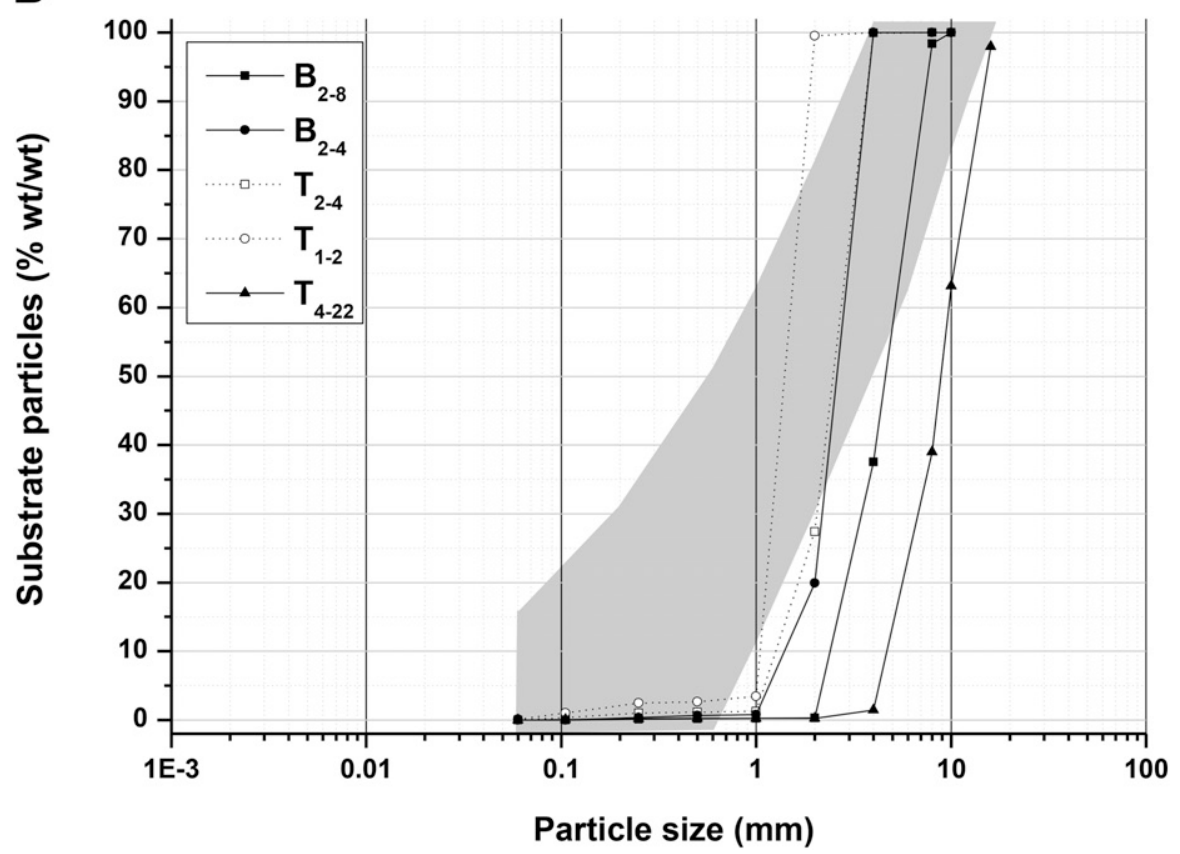

Fig. 1. Particle size distribution of the independent inorganic materials. The light gray area represents the particle size distribution proposed by the Forschungsgesellschaft Landschaftsentwicklung Landschaftsbau (2008) guidelines for extensive green roofs. (A) Crushed tiles grade 5-8 $\mathrm{mm}\left(\mathrm{T}_{5-8}\right), 5-16 \mathrm{~mm}\left(\mathrm{~T}_{5-16}\right)$; thermally treated clay (TC); pumice (Pum); and zeolite (Zeo). (B) Crushed brick grade 2-8 mm $\left(\mathrm{B}_{2-8}\right)$, 2-4 $\mathrm{mm}\left(\mathrm{B}_{2-4}\right)$ and crushed tiles grade $2-4 \mathrm{~mm}\left(\mathrm{~T}_{2-4}\right), 1-2 \mathrm{~mm}\left(\mathrm{~T}_{1-2}\right)$, and 4-22 $\mathrm{mm}$ $\left(\mathrm{T}_{4-22}\right)$. Values are the mean of three replications having a maximum $\mathrm{SE}$ of \pm 2.7 ; $1 \mathrm{~mm}=0.0394$ inch.

The $\mathrm{pH}$ was measured with an electrode (LIQ-Glass; Hamilton, Bonaduz, Switzerland) connected to a meter (Orion $\mathrm{pH} / \mathrm{ISE}$ benchtop meter 710 Aplus; Thermo Fisher Scientific, Waltham, MA) and the EC was measured with a handheld conductivity meter (CyberScan CON200; Eutech Instruments, Singapore). The $\mathrm{pH}$ and EC of the inorganic materials were determined using a $1: 5$ (wt/wt) substrate-to-deionized water extraction. Similarly, for the organic constituents, $\mathrm{pH}$ and $\mathrm{EC}$ were determined in a suspension of 1 part compost to 2 parts deionized water by volume (Helrich, 1990). All measurements were performed in triplicates.

The substrate particle size distribution was determined using a series of sieves of various sizes (American Society for Testing and Materials, 2007), which vibrated on a mechanical shaker (Vibratory Sieve Shaker AS 200 basic; Retsch, Haan, Germany). The separated grain sizes were weighed, and then the percentage of each grain size was calculated. The particle distribution of each material was plotted on a logarithmic scale to investigate their compliance with the corresponding FLL guidelines (2008).

To evaluate the water content properties of the substrate mixtures, a water potential curve was determined as described by Nektarios et al. (201lb). The method used a substrate column of $1000 \mathrm{~mm}$ height that was composed of 20 rings, each $50 \mathrm{~mm}$ in height.

The weight of the final substrates was determined at saturation by placing them in lysimeters of $150 \mathrm{~mm}$ height and $305 \mathrm{~mm}$ internal diameter. The lysimeters were filled with the appropriate substrate mix, and then they were filled slowly with water from the bottom using a peristaltic pump (FPU5-MT-220, Omegaflex; Omega Engineering, Manchester, UK) and were left to drain freely for $24 \mathrm{~h}$ to reach container capacity. After that, the substrate was pressed to 105 bars using a pressure device (Kinematik Machinery Manufacturer, Metamorfosi, Greece) (Nektarios et al., 2007). The lysimeters were saturated once again, and their saturated weight was determined using an "S type" load cell (LCl01; Omega Engineering) connected to a digital indicator (DP4l-S; Omega Engineering).

\section{Hydraulic conductivity}

The hydraulic conductivity of the substrates was determined following the U.S. Golf Association (2003) specifications. More specifically, the substrate mixes were placed in three steel tubes $100 \mathrm{~mm}$ in height and with an internal diameter of $75 \mathrm{~mm}$. The tubes were placed under constant water head of $50 \mathrm{~mm}$. After $3 \mathrm{~h}$, the draining volume was determined simultaneously for all three lysimeters along with their temperature. 


\section{Nitrate leaching}

To simulate a "first flush" event, leaching studies were performed on the final inorganic mixture. The latter was combined with four different organic amendments, namely peat, OMWC, GWC, and GMC.

Table 2. Particle size distribution compliance of selected green roof substrate inorganic mixes according to Forschungsgesellschaft

Landschaftsentwicklung

Landschaftsbau (2008).

\begin{tabular}{lcc}
\hline Material & $\begin{array}{c}\text { Volumetric } \\
\text { proportion } \\
\text { (ratio) }\end{array}$ & $\begin{array}{c}\text { Particle size } \\
\text { distribution } \\
\text { compliance }\end{array}$ \\
\hline Pum: $\mathrm{T}_{5-8}$ & $90: 10$ & Yes \\
Pum: $\mathrm{T}_{5-8}$ & $80: 20$ & No \\
Pum: $\mathrm{T}_{5-8}$ & $70: 30$ & No \\
Pum: $\mathrm{T}_{5-16}$ & $90: 10$ & Yes \\
Pum: $\mathrm{T}_{5-16}$ & $80: 20$ & No \\
Pum: $\mathrm{T}_{5-16}$ & $70: 30$ & No \\
Pum: $\mathrm{T}_{5-16}$ & $60: 40$ & No \\
Pum:TC & $90: 10$ & Yes \\
Pum:TC & $80: 20$ & Yes \\
Pum:TC & $70: 30$ & Yes \\
Pum:TC & $60: 40$ & Yes \\
\hline
\end{tabular}

Pum $=$ pumice; $T_{5-8}=$ crushed tiles grade $5-8 \mathrm{~mm}$; $\mathrm{T}_{5-16}=$ crushed tiles grade $5-16 \mathrm{~mm} ; \mathrm{TC}=$ thermally treated clay; $1 \mathrm{~mm}=0.0394$ inch.
Each substrate mixture was placed into microlysimeters of $100 \mathrm{~mm}$ height and with an internal diameter of $69 \mathrm{~mm}$. The bottom of the microlysimeters was lined with geotextile (VLF 150; Diadem, Győr, Hungary). Following their placement into the microlysimeters, the substrates were compressed by a falling weight of $2 \mathrm{~kg}$ from a height of $200 \mathrm{~mm}$. After compression, the total height of the substrates was $95 \mathrm{~mm}$. The microlysimeters were then stabilized over a fraction collector (Kinematik Machinery Manufacturer) and deionized water was poured into the microlysimeters at a rate of 100 $\mathrm{mm} \cdot \mathrm{h}^{-1}$ to simulate the maximum rainfall intensity based on 30 years of weather data for Athens, Greece. The collected leachate was analyzed for $\mathrm{NO}_{3}{ }^{-} \mathrm{N}$ using an ion-selective electrode (Orion 9707BNWP; Thermo Fisher Scientific) in conjunction with an ion benchtop meter (Orion pH/ISE Benchtop Meter 710Aplus; Thermo Fisher Scientific). An ion strength adjuster (Nitrate ISA, Orion 930711; Thermo Fisher Scientific) was added to the samples to have similar ionic strength,

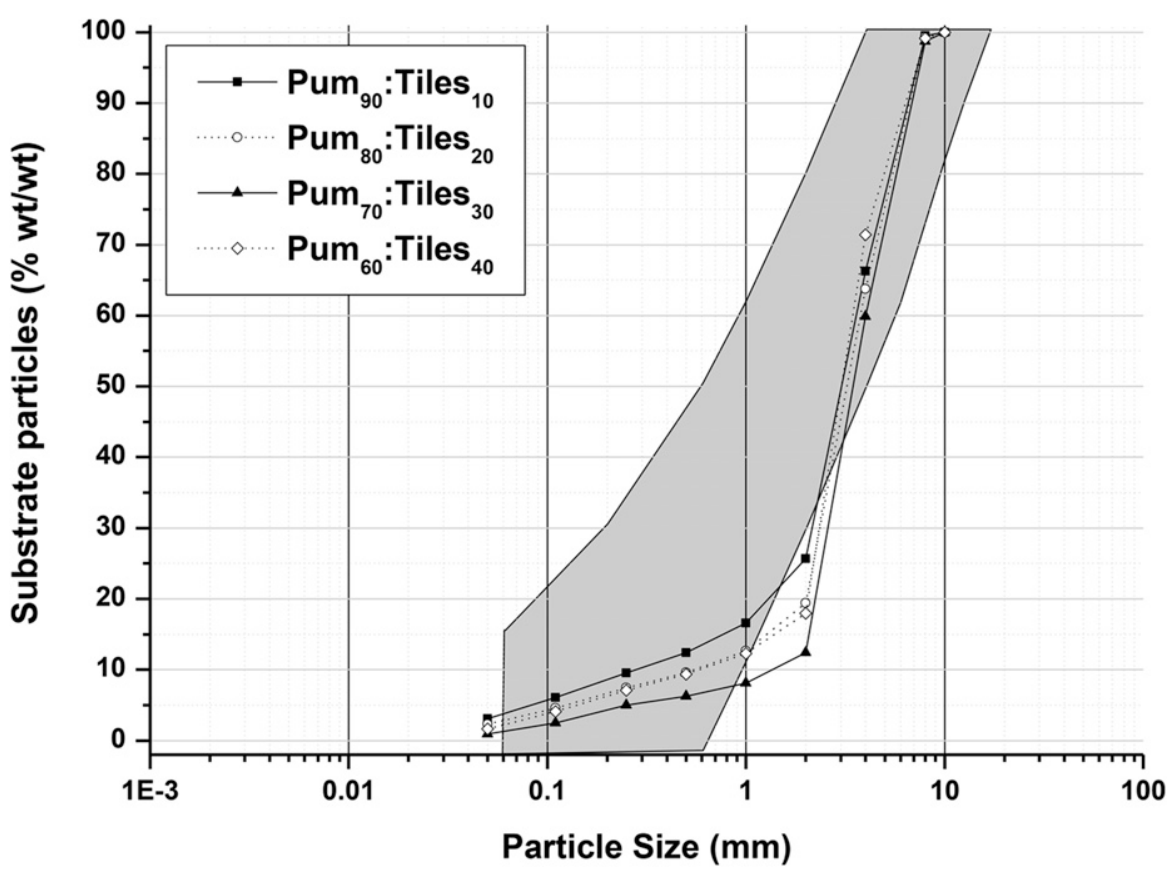

Fig. 2. Particle size distribution of crushed tiles grade 5-8 $\mathrm{mm}$ (Tiles) mixed with pumice (Pum) grade 0.05-8 $\mathrm{mm}$ at four different proportions (Pum 90 :Tiles 10 , Pum $_{80}$ :Tiles 20, Pum $_{70}:$ Tiles $_{30}$, and Pum 60 :Tiles 40$)$. The light gray area represents the particle size distribution proposed by the Forschungsgesellschaft

Landschaftsentwicklung Landschaftsbau (2008) guidelines for extensive green roofs. Values are the mean of three replications having a maximum SE of \pm 2.7 ; $1 \mathrm{~mm}=0.0394$ inch.
$\mathrm{pH}$, and minimal interference with ions.

\section{Results and discussion \\ Analysis and screening of independent materials (step 1)}

THE PH AND EC OF INDEPENDENT MATERIALs. The $\mathrm{pH}$ was high for all tested products (Table 1 ). The lowest $\mathrm{pH}$ determined was 7.75 for $\mathrm{TC}$ and 7.92 for $\mathrm{T}_{5-16}$. By contrast, the $\mathrm{pH}$ of bricks was 10.20 and 10.42 for $\mathrm{B}_{2-4}$ and $\mathrm{B}_{2-8}$, respectively. All other materials had a $\mathrm{pH}$ ranging from 8.18 to 8.85 except for Pum that had a $\mathrm{pH}$ of 9.04. Because of the increased $\mathrm{pH}$ of Pum, further studies were performed that showed a $\mathrm{pH}$ reduction from 9.04 to 8.30 within $19 \mathrm{~h}$ after its hydration (data not presented). Taking into account the increased $\mathrm{pH}$ of the crushed bricks according to FLL (2008) guidelines, both grades $\left(\mathrm{B}_{2-4}\right.$ and $\left.\mathrm{B}_{2-8}\right)$ were excluded from the remaining study.

EC of the tested materials was relatively low ranging from 30.9 to $894 \mu \mathrm{S} \cdot \mathrm{cm}^{-1}$ (Table $\mathrm{l}$ ). The only exception was the increased EC exhibited by the two crushed bricks that reached $1618 \mu \mathrm{S} \cdot \mathrm{cm}^{-1}$ for $\mathrm{B}_{2-4}$ and $1071 \mu \mathrm{S} \cdot \mathrm{cm}^{-1}$ for $\mathrm{B}_{2-8}$. The increased EC values of the bricks were presumably caused by cations, such as $\mathrm{Ca}$ and $\mathrm{Na}$, which provides a suitable explanation for the high $\mathrm{pH}$ observed for these materials while further supporting the decision to exclude them from the study.

Pumice and TC exhibited moderate EC values (291.3 and 435 $\mu \mathrm{S} \cdot \mathrm{cm}^{-1}$, respectively), whereas Zeo exhibited the lowest EC value (30.9 $\left.\mu S \cdot \mathrm{cm}^{-1}\right)$. The significant variability between the different recycled building materials indicated that their quality and capacities are region specific and that special attention is needed if they are to be used as plant substrates.

Particle size Distribution OF INDEPENDENT MATERIALS. All materials deviated from the desired particle size distribution that is suggested by FLL guidelines (2008) for extensive green roof construction except for Pum and Zeo (Fig. IA and B; Table 1). Some materials, such as $\mathrm{B}_{2-8}, \mathrm{~B}_{2-4}$, $\mathrm{T}_{2-4}, \mathrm{~T}_{1-2}$, and $\mathrm{T}_{4-22}$, deviated significantly from the guidelines, whereas others, such as TC, $\mathrm{T}_{5-8}$, and $\mathrm{T}_{5-16}$, exhibited small deviations 


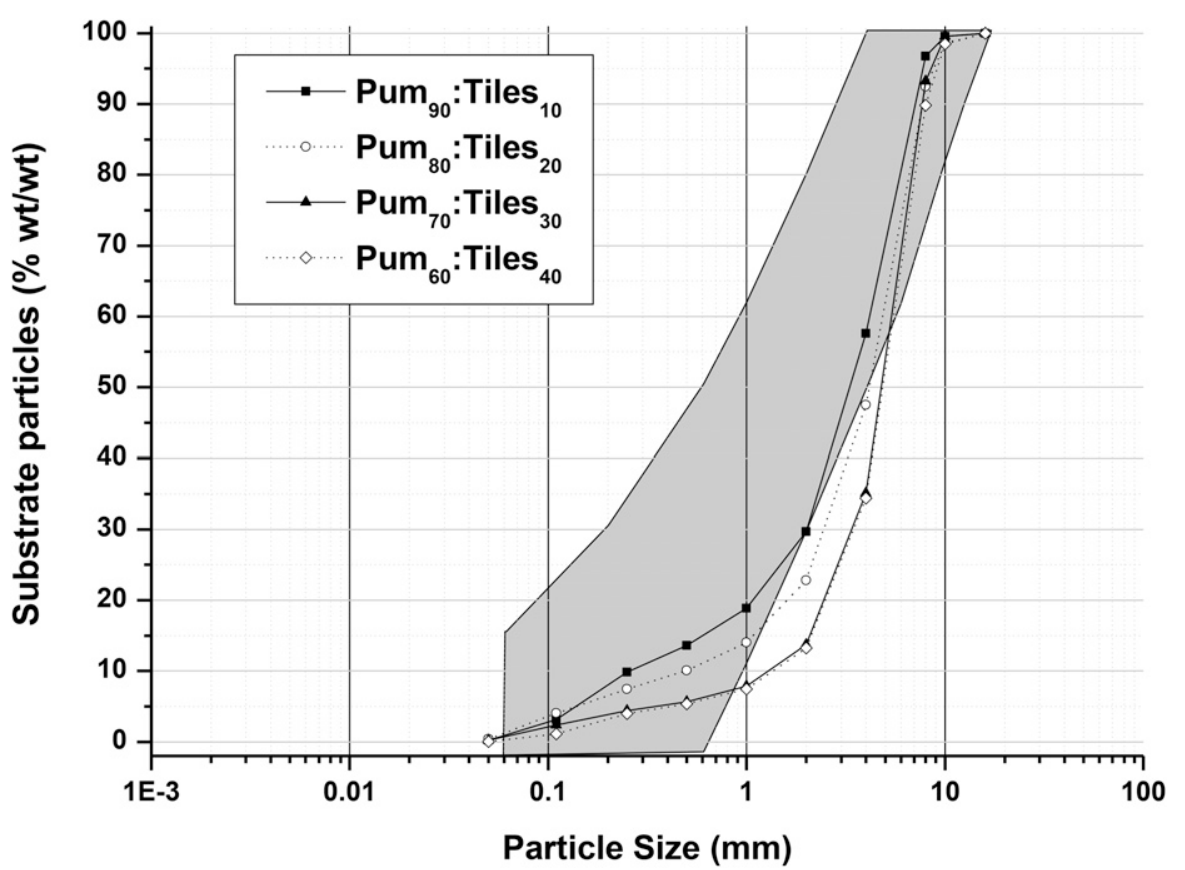

Fig. 3. Particle size distribution of crushed tiles grade 5-16 $\mathrm{mm}$ (Tiles) mixed with pumice (Pum) grade 0.05-8 $\mathrm{mm}$ at four different proportions (Pum (0) : Tiles 10, Pum $_{80}$ :Tiles 20, Pum $_{70}$ :Tiles 30 , and Pum $_{60}$ :Tiles 40 ). The light gray area represents the particle size distribution proposed by the Forschungsgesellschaft Landschaftsentwicklung Landschaftsbau (2008) guidelines for extensive green roofs. Values are the mean of three replications having a maximum SE of \pm 1.4 ; $1 \mathrm{~mm}=0.0394$ inch.

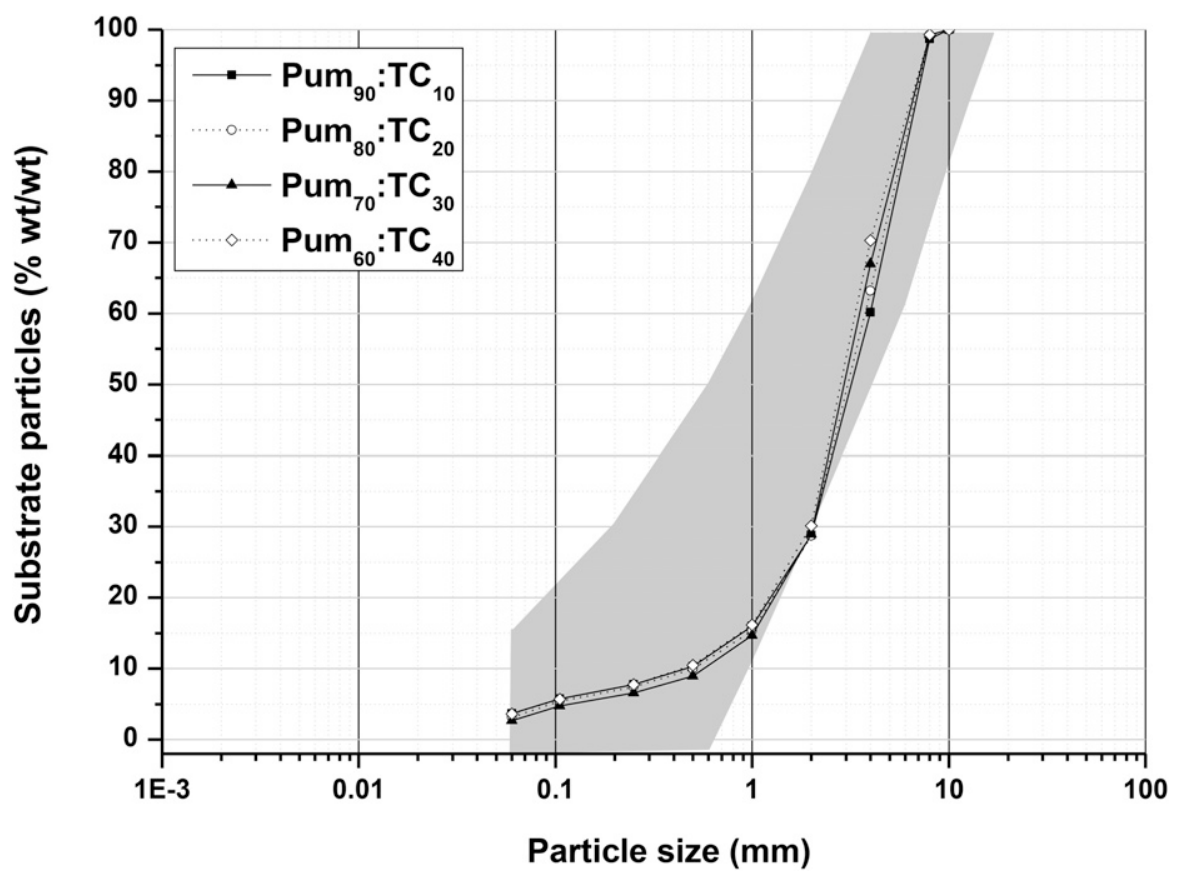

Fig. 4. Particle size distribution of thermally treated clay (TC) mixed with pumice (Pum) grade $0.05-8 \mathrm{~mm}$ at four different proportions (Pum 90 : $\mathrm{TC}_{10}$, $\operatorname{Pum}_{80}: \mathrm{TC}_{20}, \operatorname{Pum}_{70}: \mathrm{TC}_{30}$, and $\left.\mathrm{Pum}_{60}: \mathrm{TC}_{40}\right)$. The light gray area represents the particle size distribution proposed by the Forschungsgesellschaft Landschaftsentwicklung Landschaftsbau (2008) guidelines for extensive green roofs. Values are the mean of three replications having a maximum SE of \pm 0.7 ; $1 \mathrm{~mm}=0.0394$ inch. and, in particular, they were coarser in the particle size range between $\mathrm{I}$ and $5 \mathrm{~mm}$ (Fig. $\mathrm{lA}$ and $\mathrm{B}$ ).

SELECTION OF MATERIALS From THE FIRST STEP. Considering all the data collected from the first screening step of the study, it was obvious that Pum needed to be included in the substrate at an increased percentage because of its compliance with the suggested particle size distribution of the green roof guidelines (FLL, 2008). However, given the concerns raised by its high $\mathrm{pH}$, it was necessary to combine it with low$\mathrm{pH}$ materials, taking into account that current guidelines for extensive green roof substrates aim at $\mathrm{pH}$ values lower than 8.5. From the materials tested, the best candidates were $\mathrm{TC}, \mathrm{T}_{5-8}, \mathrm{~T}_{5-16}$, and Zeo (Table 1; Fig. IA and B).

\section{Analysis of inorganic mixtures (step 2)}

Following the above mentioned conclusions, Pum was mixed with $\mathrm{T}_{5-8}$ or $\mathrm{T}_{5-16}$ or $\mathrm{TC}$ at different volumetric proportions ranging from $90 \%$ to $80 \%$ to $70 \%$ to $60 \%$. On the basis of the existing literature (Huang and Petrovic, 1994; Kotsiris et al., 2013; Nektarios et al., 201 la), it was decided that Zeo would occupy a standard volumetric percentage of $5 \%$.

Particle size distributions of inORganic mixtures. Pumice mixtures with $\mathrm{T}_{5-8}$ and $\mathrm{T}_{5-16}$ did not comply with existing FLL guidelines except for the mixture where Pum had a volumetric proportion of $90 \%$ (Table 2). In both cases, particle size distribution deviated at grain size between 1 and $4 \mathrm{~mm}$ (Figs. 2 and 3 ), indicating that these materials were coarser than those described as acceptable in the FLL guidelines (2008). By contrast, the mixtures that were developed with the TC complied with existing FLL guidelines for extensive green roofing in all proportions that were used (Table 2; Fig. 4).

Moisture potential CuRves of INORGANIC MIXTURES. At this second stage, the moisture-holding capacity of each mixture was examined. A clear improvement of the moisture-holding capacity was obtained with the use of TC compared with crushed tiles (Fig. $5)$. At saturation, the water-holding 


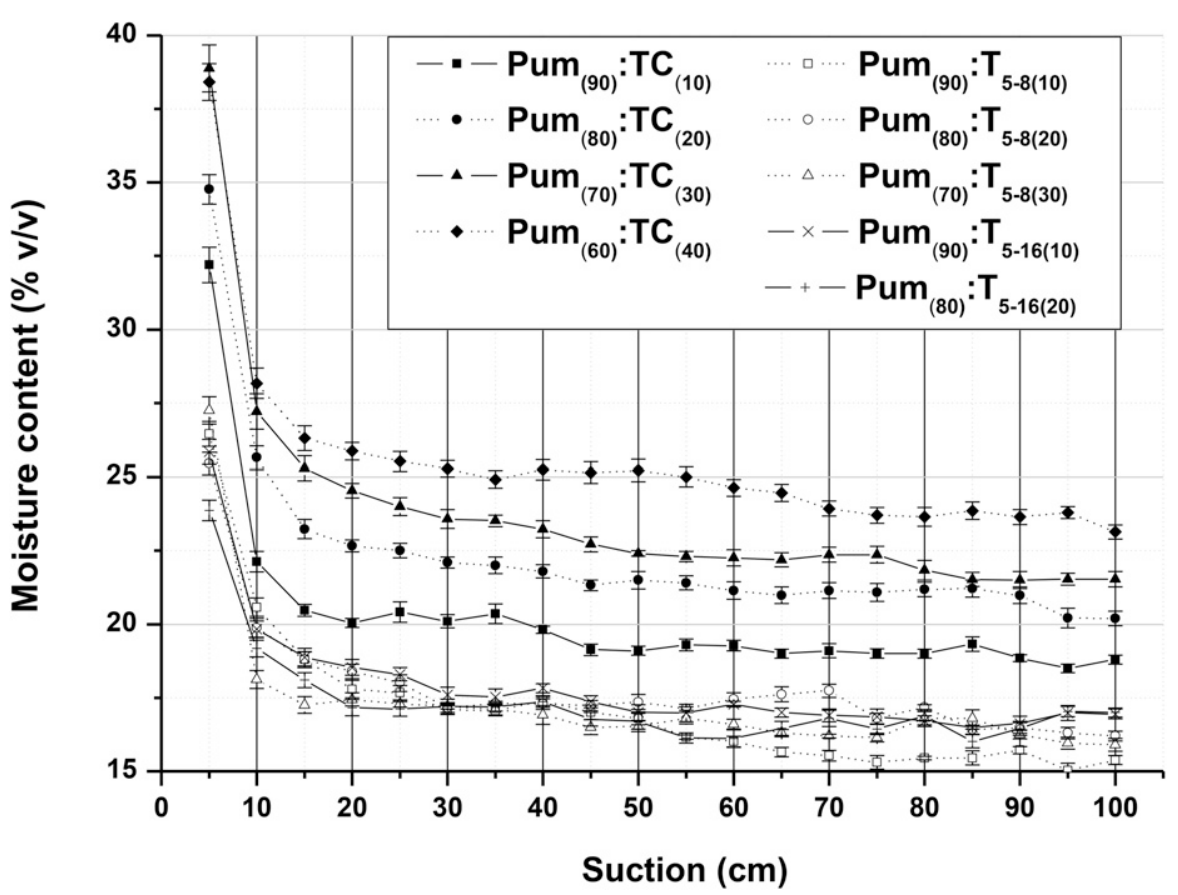

Fig. 5. Moisture potential curve for pumice (Pum) mixed at different proportions with the thermally treated clay (TC), crushed tiles grade $5-8 \mathrm{~mm}$ $\left(\mathrm{T}_{5-8}\right)$ and $5-16 \mathrm{~mm}\left(\mathrm{~T}_{5-16}\right)$ at volumetric proportions indicated by the subscripts in the parentheses. Values are the mean of three replications $( \pm S E)$; $1 \mathrm{~cm}=0.3937$ inch.

Table 3. Chemical analyses of peat and three composts that were used as substrate amendments for formulating extensive green roof substrates.

\begin{tabular}{|c|c|c|c|c|c|}
\hline \multirow[b]{2}{*}{ Analysis type } & \multirow[b]{2}{*}{ Units } & \multirow[b]{2}{*}{ Peat } & \multicolumn{3}{|c|}{ Composts } \\
\hline & & & $\overline{\mathrm{OMWC}}$ & GWC & GMC \\
\hline $\mathrm{pH}^{\mathrm{z}}$ & & 5.40 & 7.27 & 7.88 & 7.76 \\
\hline $\mathrm{EC}^{\mathrm{z}}$ & $\mu S \cdot \mathrm{cm}^{-1 \mathrm{v}}$ & 150 & 3,270 & 6,290 & 1,310 \\
\hline Water saturation & \% Dry weight & 721.98 & 122.43 & 280.85 & 191.96 \\
\hline Specific weight & & 0.19 & 0.87 & 0.47 & 0.45 \\
\hline Moisture & $\%$ & 34.60 & 25.95 & 73.05 & 57.13 \\
\hline Organic matter ${ }^{y}$ & $\%$ Dry weight & 96.67 & 39.00 & 47.67 & 88.00 \\
\hline Ash & $\%$ Dry weight & 3.33 & 61.00 & 52.33 & 12.00 \\
\hline Total nitrogen ${ }^{x}$ & $\%$ Dry weight & 0.78 & 1.69 & 1.42 & 1.74 \\
\hline Total carbon ${ }^{w}$ & $\%$ Dry weight & 55.10 & 22.23 & 27.17 & 50.16 \\
\hline $\begin{array}{l}\text { Carbon:nitrogen } \\
\text { ratio }\end{array}$ & & 70.64 & 13.15 & 19.13 & 28.83 \\
\hline Phosphorus & $\%$ Dry weight & 0.03 & 0.24 & 0.44 & 0.25 \\
\hline Calcium & $\%$ Dry weight & 0.35 & 4.52 & 11.53 & 1.98 \\
\hline Magnesium & $\%$ Dry weight & 0.06 & 0.30 & 0.40 & 0.20 \\
\hline Potassium & $\%$ Dry weight & 0.02 & 0.70 & 0.84 & 1.56 \\
\hline Sodium & $\%$ Dry weight & 0.01 & 0.03 & 0.11 & 0.08 \\
\hline Iron & $\mathrm{mg} \cdot \mathrm{kg}^{-\mathrm{lu}}$ & 327.0 & $4,827.6$ & $2,235.0$ & 877.4 \\
\hline Manganese & $\mathrm{mg} \cdot \mathrm{kg}^{-1}$ & 15.0 & 263.5 & 226.9 & 51.0 \\
\hline Zinc & $\mathrm{mg} \cdot \mathrm{kg}^{-1}$ & 11.5 & 41.4 & 86.9 & 29.3 \\
\hline Copper & $\mathrm{mg} \cdot \mathrm{kg}^{-1}$ & 3.0 & 16.1 & 5.43 & 16.0 \\
\hline Boron & $\mathrm{mg} \cdot \mathrm{kg}^{-1}$ & 5.3 & 34.0 & 26.8 & 59.0 \\
\hline
\end{tabular}

$\mathrm{EC}=$ electrical conductivity; GWC = straw, sawdust, yard waste and dairy cow, horse, and chicken manure; $\mathrm{OMWC}=$ olive mill waste compost; $\mathrm{GMC}=$ grape mark compost.

${ }^{\mathrm{z}}$ In filtrate suspension, 1 compost : 2 water (by volume).

${ }^{y}$ Combustion at $550^{\circ} \mathrm{C}\left(1022.0^{\circ} \mathrm{F}\right)$.

xKeldahl.

wBy calculating carbon as a percentage of organic matter

${ }^{\mathrm{v}} \mathrm{l} \mu \mathrm{S} \cdot \mathrm{cm}^{-1}=0.0010 \mathrm{mmho} / \mathrm{cm}$.

"By weight based on dry weight; $1 \mathrm{mg} \cdot \mathrm{kg}^{-1}=1 \mathrm{ppm}$. capacity of the TC-amended Pum was increased by $34.8 \%$ to $65.5 \%$ compared with the $\mathrm{T}_{5-8^{-}}$and $\mathrm{T}_{5-16^{-}}$ amended Pum. Moreover, there were profound differences between the three different Pum amendments $\left(\mathrm{T}_{5-8}, \mathrm{~T}_{5-16}\right.$, and $\left.\mathrm{TC}\right)$ at higher suctions (Fig. 5). More specifically, the crushed tiles amendments exhibited $17.5 \%$ moisture content at $300 \mathrm{~mm}$ suction and $15 \%$ to $17 \%$ at $1000 \mathrm{~mm}$ suction. For the same suctions, the 90\% Pum: $10 \%$ TC mix had a moisture content of $20 \%$. In addition, distinct differences were detected as the percentage of TC increased from $10 \%$ to $40 \%$, since each increment increased the water-holding capacity of the mixture by $\approx 1 \%$ to $2 \%$.

Since, the aim of the study was to develop a substrate appropriate for extensive green roofs for arid and semiarid regions, the increased water-holding capacity of TC was considered as advantageous.

CONCLUSIONS FROM THE MIXING OF THE INORGANIC PORTION OF THE SUbSTRATE. Based on all the above analyses, it was determined that TC was the best amendment for the Pumbased substrate. The highest amendment ratio of $60 \%$ Pum to $40 \%$ TC retained increased moisture content, and that was considered as a disadvantage for the rainy period of the year. Furthermore, given the slight differences between the next two mixing ratios $(80: 20$ and $70: 30)$, preference was given to the latter because of economic reasons since TC was the most expensive constituent of the substrate. For the same reason, the TC percentage was reduced further to $15 \%$. Zeolite at $5 \%$ volumetric participation completed the inorganic portion of the substrate. Thus, the inorganic portion of the mix was Pum, TC, and Zeo at $65 \%: 15 \%: 5 \%$ volumetric proportions, respectively. The remaining $15 \%$ would be occupied by the organic portion of the mixture as determined in step 3 .

\section{Selection of organic amendments (step 3)}

In an effort to reduce the horticultural use of peat, three different locally produced composts were mixed with the inorganic portion of the substrate at $15 \%$ by volume. In addition, a fourth mix that included peat served as a control for the 


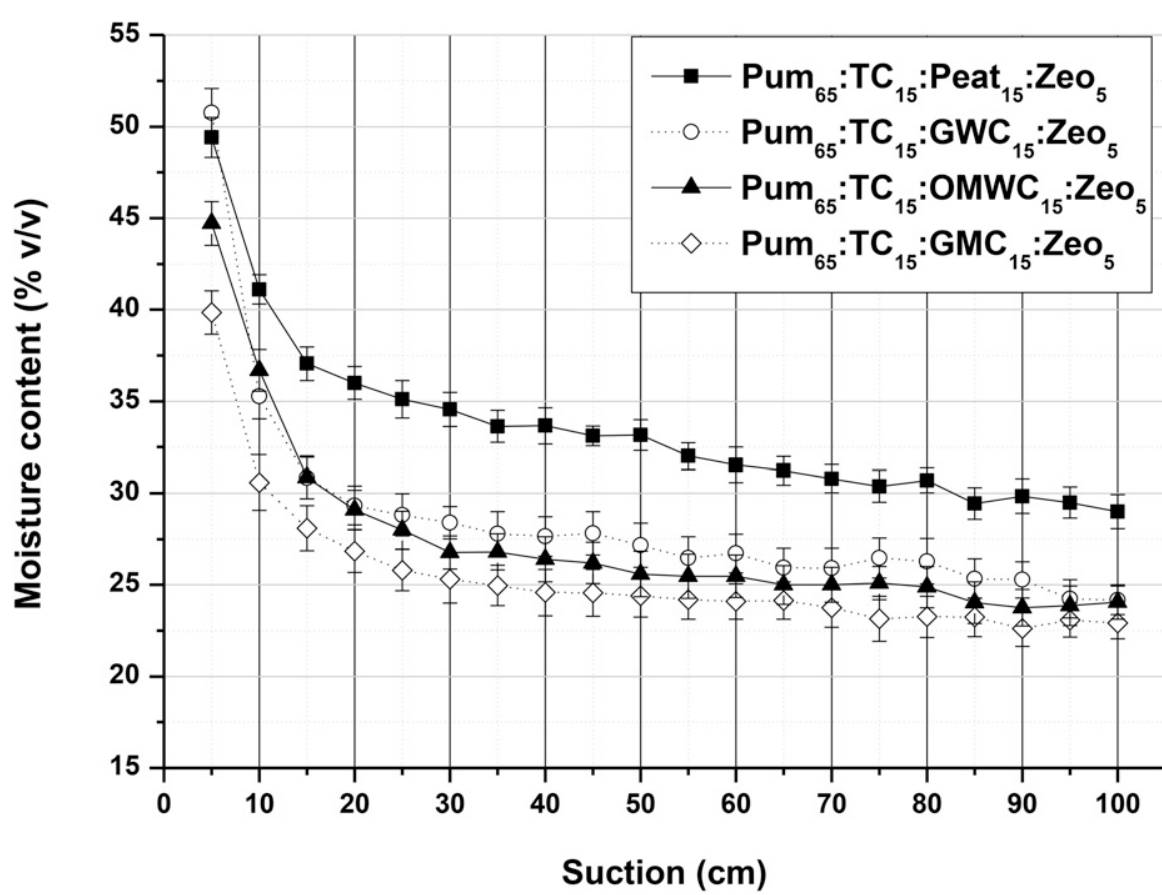

Fig. 6. Moisture potential curve for the final substrate mixture amended with different organic sources at volumetric proportions indicated by their subscripts [pumice (Pum), thermally treated product (TC), straw, sawdust, yard waste and dairy cow, horse, and chicken manure (GWC), olive mill waste compost (OMWC), grape mark compost (GMC), Clinoptilolite zeolite (Zeo)]. Values are the mean of three replications $( \pm \mathrm{SE}) ; 1 \mathrm{~cm}=0.3937$ inch.

organic amendments. The chemical and physical characteristics of all organic amendments are listed in Table 3. All composts had a $\mathrm{pH}$ ranging from 7.27 to 7.88 , whereas peat had a $\mathrm{pH}$ of 5.4. However, GWC had increased EC that reached 6290 $\mu \mathrm{S} \cdot \mathrm{cm}^{-1}$. The highest water-holding capacity was exhibited by peat, whereas GWC had higher waterholding capacity compared with GMC (Fig. 6).

Peat also had the highest organic matter (OM), whereas GMC had almost twice as much OM (88\%) compared with the other two composts. Nitrogen was similar between the three composts, but higher compared with peat. Moreover, peat and the composts exhibited differences in relation to all nutrients in that, overall, peat had minimal amounts of nutrients. Between composts, $\mathrm{P}, \mathrm{Ca}, \mathrm{Mg}$, and $\mathrm{Zn}$ were higher in GWC, with OMWC being high in $\mathrm{Fe}$ and GMC in $\mathrm{K}$ and $\mathrm{B}$.

The $\mathrm{pH}$ ranged from 7.95 to 8.35 for the compost-amended mixes, whereas the peat-amended one had a reduced $\mathrm{pH}$ of 6.16 (Table 4). Given that the FLL guidelines (2008) provide a $\mathrm{pH}$ limit from 6.0 to 8.5 , it follows that all substrate mixes comply with existing green roof guidelines for $\mathrm{pH}$. EC was at low levels for all substrates, with the highest value observed in the substrate amended with GWC $\left(680 \mu \mathrm{S} \cdot \mathrm{m}^{-1}\right)$.

Saturated hydraulic conductivity was similar between the four substrates and fell within the limits of the FLL guidelines. Although the saturated hydraulic conductivity has an extreme range in the FLL guidelines $\left(0.6-70 \mathrm{~mm} \cdot \mathrm{min}^{-1}\right)$, the values of $7.42-7.89 \mathrm{~mm} \cdot \mathrm{min}^{-1}$ (Table 4) indicate a fast-draining substrate, which is considered as advantageous in green roof systems, where minimal weight and integrity of the waterproofing layers is of the utmost importance.

The saturated and dry weight values showed small differences between the four substrates, with the lightest substrate being the one amended with GMC $\left(1092 \mathrm{~kg} \cdot \mathrm{m}^{-3}\right.$ at saturation). Friedrich (2005) and Beattie and Berghage (2004) suggested green roof bulk densities of 0.67 and $0.96 \mathrm{~g} \cdot \mathrm{cm}^{-3}$, respectively. In our case, the four substrates could be considered as lightweight since they had a dry weight closer to the lower values of the suggested dry bulk density. This characteristic is advantageous considering that it implies a reduced load on the framework of buildings. The bulk densities of all tested substrates were lower compared with other green roof substrates that have been examined in previous studies. Monterusso et al. (2005) reported a saturated bulk density of $1.5 \mathrm{~g} \cdot \mathrm{cm}^{-3}$ at $0.1 \mathrm{MPa}$ of a substrate composed of $60 \%$ heatexpanded slate, 25\% U.S. Golf Association-grade sand, 5\% compost, and $10 \%$ Michigan peat. Similarly,

Table 4. The $\mathrm{pH}$, electrical conductivity (EC), saturated hydraulic conductivity, and saturated and dry weight values determined for each one of the four substrates with varying organic amendments. Values are the mean of three replications.

\begin{tabular}{|c|c|c|c|c|c|}
\hline \multirow[b]{3}{*}{ Substrate type } & \multirow[b]{2}{*}{$\mathrm{pH}$} & \multirow[b]{2}{*}{$\mathrm{EC}\left(\mu \mathrm{S} \cdot \mathrm{cm}^{-1}\right)^{\mathrm{z}}$} & \multirow{2}{*}{$\begin{array}{c}\text { Saturated hydraulic } \\
\text { conductivity }\left(\mathrm{mm} \cdot \mathrm{min}^{-1}\right)^{\mathrm{z}}\end{array}$} & \multicolumn{2}{|c|}{$\mathrm{Wt}\left(\mathrm{kg} \cdot \mathrm{m}^{-3}\right)^{\mathrm{z}}$} \\
\hline & & & & Saturated & Dry \\
\hline & & & Mean \pm SE & & \\
\hline $\operatorname{Pum}_{65}: \mathrm{TC}_{15}: \mathrm{GWC}_{15}: \mathrm{ZeO}_{5}$ & $8.35 \pm 0.04$ & $680 \pm 6.43$ & $7.42 \pm 0.32$ & $1,234.1 \pm 12.51$ & $692.4 \pm 4.10$ \\
\hline Pum $_{65}: \mathrm{TC}_{15}: \mathrm{OMWC}_{15}: \mathrm{ZeO}_{5}$ & $7.95 \pm 0.03$ & $467 \pm 7.09$ & $7.84 \pm 0.12$ & $1,218.2 \pm 11.22$ & $733.1 \pm 4.80$ \\
\hline $\operatorname{Pum}_{65}: \mathrm{TC}_{15}: \mathrm{GMC}_{15}: \mathrm{Zeo}_{5}$ & $8.18 \pm 0.03$ & $280 \pm 3.06$ & $7.42 \pm 0.22$ & $1,092.0 \pm 8.70$ & $676.9 \pm 3.54$ \\
\hline
\end{tabular}

Pum = pumice TC $=$ thermally treated clay; $\mathrm{GWC}=$ straw, sawdust, yard waste and dairy cow, horse, and chicken manure OMWC $=$ olive mill waste compost GMC $=$ grape mark compost; Zeo = Clinoptilolite zeolite at volumetric percentages as indicated by the subscripts.

${ }^{\mathrm{z}} \mathrm{l} \mu \mathrm{S} \cdot \mathrm{cm}^{-1}=0.0010 \mathrm{mmho} / \mathrm{cm} ; 1 \mathrm{~mm}=0.0394 \mathrm{inch} ; \mathrm{l} \mathrm{kg} \cdot \mathrm{m}^{-3}=0.0624 \mathrm{lb} / \mathrm{ft}^{3}$. 


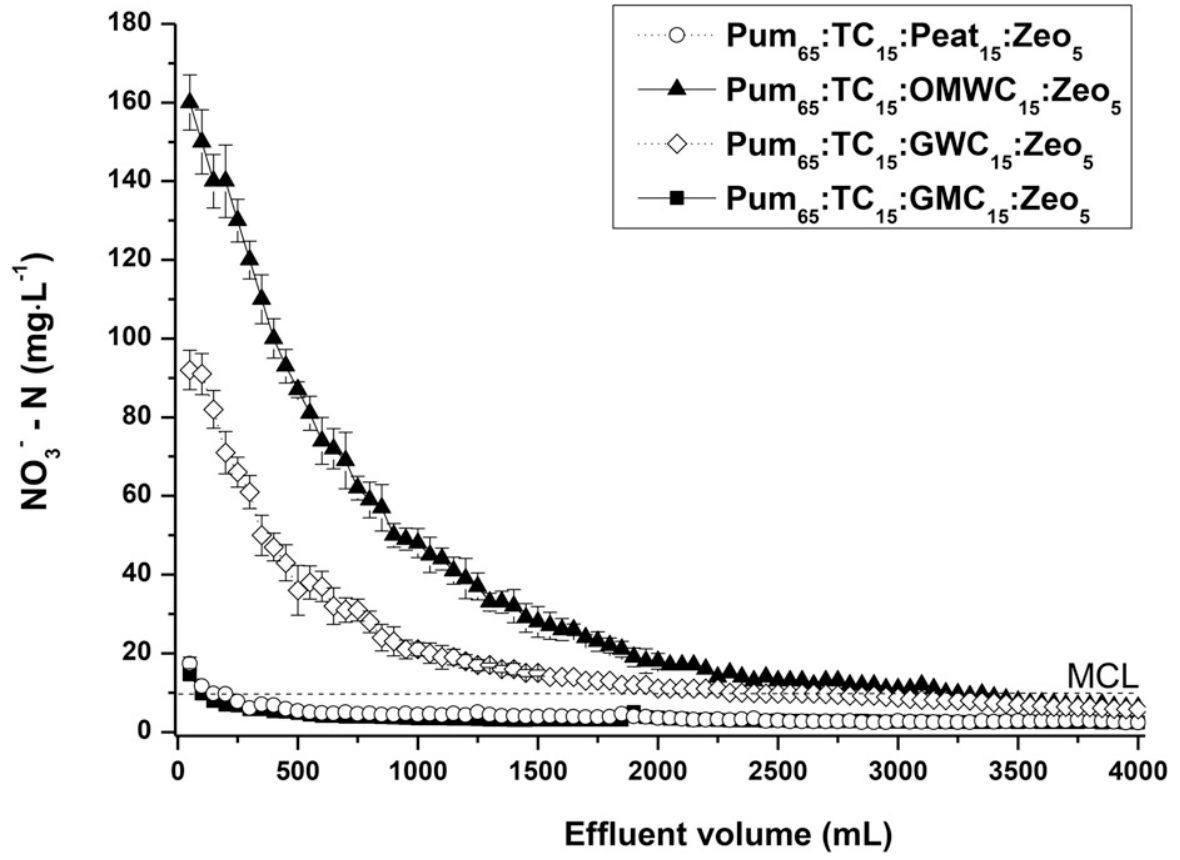

Fig. 7. Nitrate $\left(\mathrm{NO}_{3}{ }^{-}-\mathrm{N}\right)$ leaching for the final substrate mixture amended with different organic sources at volumetric proportions indicated by their subscripts [pumice (Pum), thermally treated product (TC), straw, sawdust, yard waste and dairy cow, horse, and chicken manure (GWC), olive mill waste compost (OMWC), grape mark compost (GMC), Clinoptilolite zeolite (Zeo)]. Values are the mean of three replications $( \pm S E)$. The dashed line represents the maximum contaminant level (MCL) for $\mathrm{NO}_{3}{ }^{-}-\mathrm{N}$ concentration in drinking water set by U.S. Environmental Protection Agency (2015); $1 \mathrm{mg} \cdot \mathrm{L}^{-1}=1 \mathrm{ppm}, 1 \mathrm{~mL}=0.0338 \mathrm{fl} \mathrm{oz}$.

Olszewski et al. (2010) reported bulk densities of $0.87-0.88 \mathrm{~g} \cdot \mathrm{cm}^{-3}$ for green roof substrates that were formulated by different volumetric proportions of coarse and fine heatexpanded slate mixed with compost and hydrogel.

Moisture POTENTIAL CURVES OF THE FINAL SUBSTRATE MIXTURE MIXED WITH FOUR ORGANIC AMENDMENTS. Apart from the physical and chemical characterization of the organic amendments, their moisture-holding capacity at different levels of suction was also examined. It was found that peat exhibited the highest waterholding capacity at suctions higher than $100 \mathrm{~mm}$ compared with all composts (Fig. 6). Close to saturation (50 $\mathrm{mm}$ of suction), the moisture retention of the GWC-amended substrate was similar to that of peat, indicating its ability to absorb increased amounts of water. All substrates exhibited a fast draining capacity, as indicated by the steep slope of their water potential curves between 50 and $100 \mathrm{~mm}$. This fast draining pattern of all substrates is deemed as advantageous since it provides adequate substrate porosity soon after rainfall events and contributes to considerable reduction of the load exerted on the frame of buildings. GWC and OMWC provided similar water potential curves for suctions higher than $100 \mathrm{~mm}$. By contrast, the GMC-amended substrate exhibited the least water-holding capacity of all substrates up to $400 \mathrm{~mm}$ suction. For suctions higher than $400 \mathrm{~mm}$, all compost-amended substrates behaved similarly in that they retained moisture content between $28 \%$ and $23 \% \mathrm{v} / \mathrm{v}$ (Fig. 6). The different response between the three compostamended substrates for suctions up to $400 \mathrm{~mm}$ has an impact on the easily available water (EAW) to the plants. More specifically, OMWC, GWC, and GMC provided 9.9\%, $6.9 \%$, and $5.3 \%$ of EAW, respectively, whereas peat provided $6.5 \%$ of EAW, indicating that OMWC is the organic amendment that provides the most water to the green roof plants.

CONCLUSIONS FROM THE SELECTION OF THE ORGANIC AMENDMENTS (THIRD STEP). According to the findings of the third screening step, peat provided superior water-holding capacity compared with all tested composts. Thus, it would be the preferred organic amendment for arid and semiarid Mediterranean regions, where the lack of water resources is one of the main restraints to urban greening and prohibits the use of adequate irrigation on green roofs. In addition, existing literature indicates that composts produce lush growth, thus, imposing increased stress on plants that enter drought periods (Ntoulas et al., 2012, 2013a, 2013b). Similarly, Nagase and Dunnett (2011) indicated that $\mathrm{OM}$ should preferably be $10 \%$ by volume to avoid plant drought stress in extensive green roofs.

However, taking into account the substantial difference in $\mathrm{CO}_{2}$ carbon footprint between peat and composts (Kotsiris et al., 2013) in conjunction with the nonsustainable depletion of peat bogs, it is obvious that an alternative solution must be implemented. Composts are a suitable alternative to peat utilization in urban greening (Nektarios et al., 201la, 2015) and, in this case, each of the three composts could be used as organic amendment in the extensive green roof plant growth substrate. However, GWC is a less preferred choice due to its increased EC. Regarding the two remaining composts, OMWC exhibited better water-holding characteristics and provided higher EAW values. However, for all compost-amended substrates the waterretaining capacity was increased due to the inorganic portion of the substrate mixes and, thus, considering that GMC had increased OM, which is close to that of peat, it was preferred compared with OMWC.

\section{Nitrate leaching potential of the final substrate mixture mixed with four organic amendments (step 4)}

Nitrate leaching was significantly different between the four substrates (Fig. 7). Those amended with OMWC and GWC exhibited increased leaching that reached 160 and $92 \mathrm{mg} \cdot \mathrm{L}^{-1}$, respectively. In both substrates, nitrate leaching was reduced progressively and reached a level below the maximum contaminant lever (MCL) of $10 \mathrm{mg} \cdot \mathrm{L}^{-1}$ after 3250 and $2400 \mathrm{~mL}$ of effluent volume for OMWC and GWC, respectively. By contrast, peat and GMC exhibited only limited nitrate 
leaching (initial concentration of 17.3 and $14.6 \mathrm{mg} \cdot \mathrm{L}^{-1}$, respectively) that reached values below the MCL almost immediately after the initiation of the leaching study (within 100 and $50 \mathrm{~mL}$ of effluent volume, respectively).

Nitrates resulting from different green roof systems are considered to be a potential contaminant. Vijayaraghavan et al. (2012) reported that $\mathrm{NO}_{3}{ }^{-} \mathrm{N}$ leaching from two different green roof substrate types could be considered as a potential hazard for green roof infrastructure deployment, although their concentration did not exceed the U.S. Environmental Protection Agency (2015) recommended freshwater standards. By contrast, van Seters et al. (2009) reported minimal $\mathrm{NO}_{3}{ }^{-}-\mathrm{N}$ leaching from a green roof, which was less compared with a conventional rooftop. In general, $\mathrm{NO}_{3}{ }^{-}-\mathrm{N}$ leaching from green roof systems has been found to depend on substrate composition, rainfall inputs, and fertilizer type (Emilsson et al., 2007). From our research it was found that, as reported by Czemiel Berndtsson et al. (2008), substrate composition can have an impact on runoff water quality at first flush. More specifically, based on our findings, green roof substrate composition will influence the amount of $\mathrm{NO}_{3}{ }^{-} \mathrm{N}$ leaching in newly constructed green roof systems when plants have not yet established their root systems and $\mathrm{NO}_{3}{ }^{-} \mathrm{N}$ absorbance is expected to be limited.

\section{Conclusions}

The present study evaluated the potential of locally available materials to constitute a green roof growing substrate capable of supporting plant sustainable growth in the demanding arid and semiarid climatic conditions of the Mediterranean region. Ten inorganic and four organic materials were investigated for their characteristics and their compliance with existing green roof guidelines. From the inorganic materials, Pum, TC, and Zeo were found to be the most appropriate ones based on their particle size distribution and moistureretaining capacity. From the organic sources, either peat or GMC were found to be the most appropriate ones that also possessed minimal $\mathrm{NO}_{3}{ }^{-}-\mathrm{N}$ leaching.

\section{Literature cited}

Akbari, H., M. Pomerrantz, and H. Taha. 2001. Cool surfaces and shade trees to reduce energy use and improve air quality in urban areas. Sol. Energy 70:295-310.

American Society for Testing and Materials. 2007. Standard test methods for moisture, ash, and organic matter of peat and other organic soils. ASTM International, West Conshohocken, PA.

Beattie, D.J. and R.D. Berghage. 2004. Green roof media characteristics: The basic, p. 411-416. In: Proc. 2nd North Amer. Green Roof Conf.: Greening Rooftops for Sustainable Communities Conf., Portland, OR, 2-4 June 2004. Cardinal Group, Toronto, ON, Canada.

Czemiel Berndtsson, J., L. Bengtsson, and K. Jinno. 2008. First flush effect from vegetated roofs during simulated rain events. Hydrol. Res. 39:171-179.

Dunnett, N. and N. Kingsbury. 2010. Planting green roofs and living walls. 2 nd ed. Timber Press, Cambridge, UK.

Emilsson, T., J.C. Berndtsson, J.E. Mattsson, and K. Rolf. 2007. Effect of using conventional and controlled release fertiliser on nutrient runoff from various vegetated roof systems. Ecol. Eng. 29:260271.

Forschungsgesellschaft Landschaftsentwicklung Landschaftsbau. 2008. Guidelines for the planning, construction and maintenance of green roofing-green roofing guideline. FLL, Bonn, Germany.

Friedrich, C.R. 2005. Principles for selecting the proper components for a green roof growing media, p. 262-273. Proc. 3rd North Amer. Green Roof Conf.: Greening rooftops for sustainable communities. Washington, D.C., 4-6 May 2005. Cardinal Group, Toronto, ON, Canada.

Getter, L.K. and D.B. Rowe. 2006. The role of extensive green roofs in sustainable development. HortScience 41:12761285.

Helrich, K. 1990. Official methods of analysis of the Association of Official Analytical Chemists. 15th ed. AOAC 973.04. Assn. Offic. Anal. Chemists, Arlington, VA.

Huang, Z.T. and A.M. Petrovic. 1994. Clinoptilolite zeolite influence on nitrate leaching and nitrogen use efficiency in simulated sand based golf greens. J. Environ. Qual. 23:1190-1194.

Kotsiris, G., P.A. Nektarios, N. Ntoulas, and G. Kargas. 2013. An adaptive approach to intensive green roofs in the Mediterranean. Urban For. Urban Green. 12:380-392.
Kotsiris, G., P.A. Nektarios, and A.T. Paraskevopoulou. 2012. Lavandula angustifolia growth and physiology is affected by substrate type and depth when grown under Mediterranean semiintensive green roof conditions. HortScience 47:311-317.

Monterusso, M.A., D.B. Rowe, and C.L. Rugh. 2005. Establishment and persistence of Sedum spp. and native taxa for green roof applications. HortScience 40:391-396.

Nagase, A. and N. Dunnett. 2011. The relationship between percentage of organic matter in substrate and plant growth in extensive green roofs. Landsc. Urban Plan. 103:230-236.

Nektarios, P.A., I. Amountzias, I. Kokkinou, and N. Ntoulas. 2011a. Green roof substrate type and depth affects the growth of the native species Dianthus fruticosus under reduced irrigation regimes. HortScience 46:1208-1216.

Nektarios, P.A., S. Kastritsis, N. Ntoulas, and P. Tsiotsiopoulou. 2011b. Substrate amendment effects on potted plant production and dry weight partition of Lantana camara. HortScience 46:864-869.

Nektarios, P.A., N. Ntoulas, E. Nydrioti, I. Kokkinou, E.-M. Bali, and I. Amountzias. 2015. Drought stress response of Sedum sediforme grown in extensive green roof systems with different substrate types and depths. Sci. Hort. 181:52-61.

Nektarios, P.A., A.M. Petrovic, and T.S. Steenhuis. 2007. Preferential flow in simulated greenhouse golf putting green profiles as affected by aeration and two soil moisture regimes. Soil Sci. 172:108-123.

Nektarios, P.A., P. Tsiotsiopoulou, and I. Chronopoulos. 2003. Soil amendments reduce roof garden weight and influence the growth rate of Lantana. HortScience 38:618-622.

Nikologianni, A., P. Andreou, P.A. Nektarios, and A.N. Markoglou. 2009. Metalaxyl-m leaching from different substrates and drainage systems in intensive green roofs. Acta Hort. 881:725-728.

Ntoulas, N., P.A. Nektarios, E. Charalambous, and A. Psaroulis. 2013a. Zoysia matrella cover rate and drought tolerance in adaptive extensive green roof systems. Urban For. Urban Green. 12:522-531.

Ntoulas, N., P.A. Nektarios, and E. Nydrioti. 2013b. Performance of Zoysia matrella 'Zeon' in shallow green roof substrates under moisture deficit conditions. HortScience 48:929-937.

Ntoulas, N., P.A. Nektarios, K. Spaneas, and N. Kadoglou. 2012. Semi-extensive 


\section{Research Reports}

green roof substrate type and depth effects on Zoysia matrella 'Zeon' growth and drought tolerance under different irrigation regimens. Acta Agriculturae Scandinavica, Section B Plant Soil Sci. 62:165-173.

Olszewski, M.W., M.H. Holmes, and C. A. Young. 2010. Assessment of physical properties and stonecrop growth in green roof media amended with compost and hydrogel. HortTechnology 20:438-444.

Rowe, D.B., M.A. Monterusso, and C.L. Rugh. 2006. Assessment of heat-expanded slate and fertility requirements in green roof substrates. HortTechnology 16:471-477.

Scrivens, S. 1990. Urban landscape and roof gardens, p. 131-151. In: B. Clouston (ed.). Landscape design with plants. 2nd ed. Butterworth-Heinemann, Oxford, UK.

Spronken-Smith, R.A. and T.R. Oke. 1998. The thermal regime of urban parks in two cities with different summer climates. Intl. J. Remote Sens. 19:2085-2104.
Takebayashi, H. and M. Moriyama. 2009 Study on the urban heat island mitigation effect achieved by converting to grasscovered parking. Sol. Energy 83:1211-1223.

Thuring, C.E., R.D. Berghage, and D.J. Beattie. 2010. Green roof plant responses to different substrate types and depths under various drought conditions. HortTechnology 20:395-401.

Tsiotsiopoulou, P., P.A. Nektarios, and I. Chronopoulos. 2003. Substrate temperature fluctuation and dry weight partitioning of Lantana grown in four green roof growing media. J. Hort. Biotechnol. 78:904-910.

U.S. Environmental Protection Agency. 2015. Basic Information about Nitrate in Drinking Water. 20 Oct. 2015. <http:// water.epa.gov/drink/contaminants/ basicinformation/nitrate.cfm\#four>.

U.S. Golf Association. 2003. Recommendations for a Method of Putting
Green Construction. 20 Oct. 2015. <http://usga.org/course_care/articles/ construction/greens/Green-SectionRecommendations-For-A-Method-OfPutting-Green-Construction>.

van Seters, T., L. Rocha, D. Smith, and G. MacMillan. 2009. Evaluation of green roofs for runoff retention, runoff quality, and leachability. Water Qual. Res. J. Canada $44: 33-47$.

Vijayaraghavan, K., U.M. Joshi, and R. Balasubramanian. 2012. A field study to evaluate runoff quality from green roofs. Water Res. 46:1337-1345.

Williams, S.G.N., P.J. Rayner, and J.K. Raynor. 2010. Green roofs for a wide brown land: Opportunities and barriers for rooftop greening in Australia. Urban For. Urban Green. 9:245-251. 